American Journal of Applied Sciences 7 (1): 56-62, 2010

ISSN 1546-9239

(C) 2010 Science Publications

\title{
Isolation and Characterization of Thermophilic Cellulase-Producing Bacteria from Empty Fruit Bunches-Palm Oil Mill Effluent Compost
}

\author{
${ }^{1}$ Azhari Samsu Baharuddin, ${ }^{2}$ Mohamad Nafis Abd Razak, ${ }^{2}$ Lim Siong Hock, ${ }^{2}$ Mohd Najib Ahmad, \\ ${ }^{2}$ Suraini Abd-Aziz, ${ }^{2}$ Nor' Aini Abdul Rahman, ${ }^{2}$ Umi Kalsom Md Shah, \\ ${ }^{2}$ Mohd Ali Hassan, ${ }^{3}$ Kenji Sakai and ${ }^{1}$ Yoshihito Shirai \\ ${ }^{1}$ Department of Biological Functions and Engineering, \\ Graduate School of Life Science and System Engineering, Kyushu Institute of Technology, \\ 2-4 Hibikino, Wakamatsu-Ku, Kitakyushu, Fukuoka 808-0916, Japan \\ ${ }^{2}$ Department of Bioprocess Technology, Faculty of Biotechnology and Biomolecular Sciences, \\ University Putra Malaysia, 43400 UPM Serdang, Selangor, Malaysia \\ ${ }^{3}$ Department of Plant Resources, Graduate School of Bioresources and Bioenvironmental Sciences, \\ Kyushu University, 6-10-1, Higashi-Ku, Fukuoka, 812-8581, Japan
}

\begin{abstract}
Problems statement: Lack of information on locally isolated cellulase-producing bacterium in thermophilic compost using a mixture of Empty Fruit Bunch (EFB) and Palm Oil Mill Effluent (POME) as composting materials. Approach: The isolation of microbes from compost heap was conducted at day 7 of composting process where the mixture of composting materials consisted of $45.8 \%$ cellulose, $17.1 \%$ hemicellulose and $28.3 \%$ lignin content. The temperature, $\mathrm{pH}$ and moisture content of the composting pile at day 7 treatment were $58.3,8.1$ and $65.5^{\circ} \mathrm{C}$, respectively. The morphological analysis of the isolated microbes was conducted using Scanning Electron Microscope (SEM) and Gram stain method. The congo red test was conducted in order to detect $1 \%$ CMC agar degradation activities. Total genomic DNAs were extracted from approximately $1.0 \mathrm{~g}$ of mixed compost and amplified by using PCR primers. The PCR product was sequent to identify the nearest relatives of $16 \mathrm{~S}$ rRNA genes. The localization of bacteria chromosomes was determined by Fluorescence In Situ Hybridization (FISH) analysis. Results: Single isolated bacteria species was successfully isolated from Empty Fruit Bunch (EFB)-Palm Oil Mill Effluent (POME) compost at thermophilic stage. Restriction fragment length polymorphism profiles of the DNAs coding for the $16 \mathrm{~S}$ rRNAs with the phylogenetic analysis showed that the isolated bacteria from EFB-POME thermophilic compost gave the highest homology $(99 \%)$ with similarity to Geobacillus pallidus. The strain was spore forming bacteria and able to grow at $60^{\circ} \mathrm{C}$ with $\mathrm{pH}$ 7. Conclusion: Thermophilic bacteria strain, Geobacillus pallidus was successfully isolated from Empty Fruit Bunch (EFB) and Palm Oil Mil Effluent (POME) compost and characterized.
\end{abstract}

Key words: Cellulase, thermophilic bacteria, composting, empty fruit bunch, palm oil mill effluent

\section{INTRODUCTION}

Composting can be defined as the controlled biological decomposition of organic substrates carried out by successive microbial populations combining both mesophilic and thermophilic activities, leading to the production of a final product sufficiently stable for agricultural field without adverse environmental effects (Iyengar and Bhave, 2005). Composting of Empty Fruit Bunch (EFB) and Palm Oil Mill Effluent (POME) is one of the alternative ways to reduce the amount of by product and towards the zero emission programs in palm oil mill industry (Hassan et al., 2002; Baharuddin et al., 2009). The composting process typically undergoes a series of temperatures which are rapid increase in temperature, a period of sustained high temperature and followed by the slow cooling of the compost (Dees and Ghiorse, 2001).

EFB contain a high proportion of cellulosic matter which is easily decomposed by a combination of

Corresponding Author: Suraini Abd-Aziz, Department of Bioprocess Technology,

Faculty of Biotechnology and Biomolecular Sciences, University Putra Malaysia,

43400 UPM Serdang, Selangor, Malaysia Tel: +603-8946 7479 
Am. J. Applied Sci., 7 (1): 56-62, 2010

physical, chemical and biological processes. The bunch consists of 70 moisture and $30 \%$ solid; of which holocellulose accounts for 65.5, lignin 21.2, ash 3.5, hot water-soluble substances 5.6 and alcohol-benzene soluble $4-1 \%$ (Thambirajah et al., 1995). Lignin is an integral cell wall constituent, which provides plant strength and resistance to microbial degradation (Shibata et al., 2008). Many microorganisms are capable of degrading and utilizing cellulose and hemicellulose as carbon and energy sources. During composting, the capacity of thermophilic microorganisms to assimilate organic matter depends on their ability to produce the enzymes needed for degradation of the substrate (Tuomela et al., 2000).

Enzymatic hydrolysis processing of cellulosic materials could be accomplished through a complex reaction of various enzymes. Cellulases are inducible enzymes which are synthesized by microorganisms during their growth on cellulosic materials (Lee and Koo, 2001; Cai et al., 1999). Therefore, there have been much research aimed in obtaining new microorganisms producing cellulase enzymes with greater efficiency. Bacteria, which has high growth rate as compared to fungi has good potential to be used in cellulase production (Ariffin et al., 2008). Thermostable cellulase can increase the rate of reaction, decrease amount of enzyme needed, longer half-life and decrease the possibility of microbial contamination (Ibrahim and El-diwany, 2007). Applications of cellulase are in detergent, textile and paper industries. The aim of this study is to identify and characterize thermophilic cellulase-producing bacteria isolated from Empty Fruit Bunches (EFB) and Palm Oil Mill Effluent (POME) compost.

\section{MATERIALS AND METHODS}

Composting facilities: The composting facilities studied represent the open windrow composting process at FELDA Maokil, Johor, Malaysia to treat the Empty Fruit Bunch (EFB) and partially treated Palm Oil Mill Effluent (POME) in field scale operation (Baharuddin et al., 2009). The composting materials obtained from the oil palm processing mill. The shredded EFB and partially treated POME were mixed at 40 and 120 tonnes, respectively. Wastewater treatment facility in Maokil palm oil mill comprises of ponding system (cooling pond, mixing pond, anaerobic ponds, facultative ponds and algae ponds) constructed to treat POME before safely discharge. POME used was collected from anaerobic pond (partially treated) and sprayed directly onto the composting piles throughout the process.
Compost samples: The compost samples were taken at day 7 of composting process $\left(55-60^{\circ} \mathrm{C}\right)$. A total of $5 \mathrm{~kg}$ compost material in the different thermophilic zone was taken and mixed. These samples are used for microbiological studies and analysis of cellulose, hemicellulose and lignin content. The sample was stored at $-20^{\circ} \mathrm{C}$ to reduce the bacteria activity. Analysis of cellulose, hemicellulose and lignin content were determined according to Umi kalsom et al. (1997).

Screening and isolation of spore-forming bacteria: The compost samples were placed in a water bath at $70^{\circ} \mathrm{C}$ for 1 day to eliminate the non-spore forming bacteria (Beffa et al., 1996). The samples were suspended and serially diluted in sterile distilled water up to $10^{-8}, 100 \mu \mathrm{L}$ of each dilution were spread on nutrient agar plate and incubated at $60^{\circ} \mathrm{C}$ for 3 days. Single colonies on the plates were isolated and purified by transferring them several times onto fresh CMC agar plates. The isolated colonies were further incubated at $60^{\circ} \mathrm{C}$ for 3 days to allow for the secretion of cellulose (Ariffin et al., 2008). The purity of colonies was ensured by the pattern of bacteria growth on the plate and microscopically (Ziad et al., 2007).

Enrichment of cellulases producers: Thermophilic bacteria were isolated and purified using streaking method on Carboxymethylcellulose (CMC) agar containing $2 \mathrm{~g} \mathrm{~L}^{-1}$ yeast extract, $4 \mathrm{~g} \mathrm{~L}^{-1}$ beef extract, 5 peptone, $10 \mathrm{CMC}, 1 \mathrm{KH}_{2} \mathrm{PO}_{4}, 0.2 \mathrm{MgSO}_{4}, 3 \mathrm{CaCl}_{2}$, $111 \mathrm{Na}_{2} \mathrm{HPO}_{4}, 0.28 \mathrm{mg} \mathrm{L}^{-1} \mathrm{FeCl} 3,0.01 \mathrm{~g} \mathrm{~L}^{-1} \mathrm{~L}-$ cysteine and $20 \mathrm{~g} \mathrm{~L}^{-1}$ agar. The $\mathrm{pH}$ of medium was adjusted to 7.0 with $1 \mathrm{M} \mathrm{NaOH}$ before autoclaving. The broth media seeded with pure culture bacteria was incubated aerobically $(170 \mathrm{rpm})$ at $60^{\circ} \mathrm{C}$ in a $250 \mathrm{~mL}$ flask.

Morphological studies: The cell sample was prepared according to standard Scanning Electron Microscopy (SEM) samples preparation procedures. Philips XL 30 ESEM (Holland) scanning electron microscope was used to view the morphological properties. Bacteria gram staining was used according to Hucker modification method. Motility test was determined by phase contrast microscopy with wet mounts and hanging drop preparations (Ziad et al., 2007).

Detection of cellulase activity: Extracellular cellulases were tested using agar plate containing $1 \%(\mathrm{w} / \mathrm{v})$ carboxymethylcellulose (CMC) ( $\mathrm{pH}$ 7.0). The pure culture on agar plates was flooded with aqueous solution of congo red $(1 \% \mathrm{w} / \mathrm{v})$ for $15 \mathrm{~min}$ to detect cellulase production. The congo red solution was then 
Am. J. Applied Sci., 7 (1): 56-62, 2010

poured off and the plates were destained with $1 \mathrm{M} \mathrm{NaCl}$ for $15 \mathrm{~min}$. The formation of a clear zone of hydrolysis indicated cellulose degradation by microorganism (Ariffin et al., 2008).

16S rRNA gene sequence: The 16S rDNA sequence of the strain was determined from genomic DNA isolated from pure culture bacteria shake flask. Extraction of DNA was carried out by using GF 1 DNA Extraction Kit (Vivantis (M) Sdn Bhd). PCR amplification was performed in a final reaction tube of $106.8 \mu \mathrm{L}$ and the reaction mixture contained each primer at a concentration of 3 , deoxynucleoside triphosphate at a concentration of $3,15 \mathrm{MgCl}$ and $1.2 \mu \mathrm{M}$ of Taq DNA polymerase. The PCR reaction was run for 30 cycles in a DNA thermal cycler (Model Takara). The following thermal profile was used for the PCR: denaturation at $94^{\circ} \mathrm{C}$ for $1 \mathrm{~min}$, primer annealing at $60^{\circ} \mathrm{C}$ for $1 \mathrm{~min}$ and extension at $72^{\circ} \mathrm{C}$ for $1 \mathrm{~min}$. The final cycle included extension for $10 \mathrm{~min}$ at $72^{\circ} \mathrm{C}$ to ensure full extension of the products. The amplified PCR products were then analyzed in a $1.0 \%(\mathrm{w} / \mathrm{v})$ agarose gel and dye with gel red. The 16S-rDNA gene sequence of the isolates was performed by Vivantis (M) Sdn Bhd by following the manufacturer's instruction.

Fluorescence in Situ Hybridization (FISH) analysis: The pure culture bacteria were fixed onto slide with fixing solution containing 4\% paraformaldehyde for three hours. The fixing solution was removed and the cells were washed by centrifugation. PhosphateBuffered Saline (PBS) and cold ethanol were added to the bacteria. The fixed bacteria were transferred to well slide and was incubated in $46^{\circ} \mathrm{C}$ for $30 \mathrm{~min}$. Fixed bacteria were spotted onto Vectabond (Vector Laboratories)-coated eight-well glass slides. After the samples were dried at room temperature, the glass slides were immersed into 50, 80 and $90 \%$ ethanol for 3 min each to dehydrate the specimens. Lysozyme solution was added after the ethanol was dried. The slide was incubated at $30^{\circ} \mathrm{C}$ for 20 min on wet filter paper. Slide was rinsed slowly with sterile distilled water and dried. Hybridization buffer and eubacteria probes (EUB 338) were added to the bacteria. The probe sequence used was 5'-GCT GCC TCC CGT AGG AGT-3'. Bacteria were incubated at $46^{\circ} \mathrm{C}$ for $2 \mathrm{~h}$ on wet filter paper containing hybridization buffer and washed with washing solution (Tris-HCl, SDS, ETDA and $\mathrm{NaCl}$ ). The bacteria were incubated at $48^{\circ} \mathrm{C}$ for $20 \mathrm{~min}$ and washed with sterile distilled water. Antifading agent was dropped onto the bacteria and covered with cover slip. The slide was observed under
Confocal Florescence Microscope (Sekiguchi et al., 1999).

\section{RESULTS}

Composting characteristic: The temperature of the compost pile at day 7 was $58.3 \pm 2.1{ }^{\circ} \mathrm{C}$ indicated the thermophilic phase occurred during the composting with moisture content of $65.5 \pm 5.8 \%$ and $\mathrm{pH}$ of $8.1 \pm 0.8$. The structure of EFB which consisted firmly bounded threads of lignin with smooth surface along the structure were altered which was shown by the present of many holes indicating the lignin has been disrupted (Fig.1a). The SEM observation of the similar compost sample shows the mixture of microbial attachment on the surface of disrupted EFB (Fig. 1b). The identification of the bacteria strain in this compost sample was done using isolation and 16S DNA extraction methods. Figure 2 shows the composition of cellulose, hemicellulose and lignin content of the compost samples throughout the composting process.

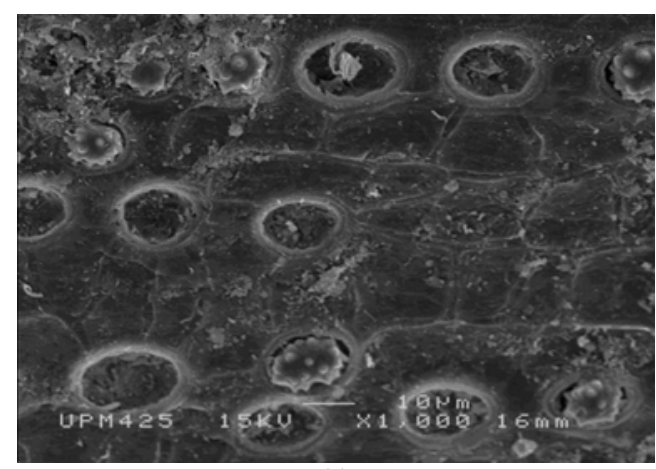

(a)

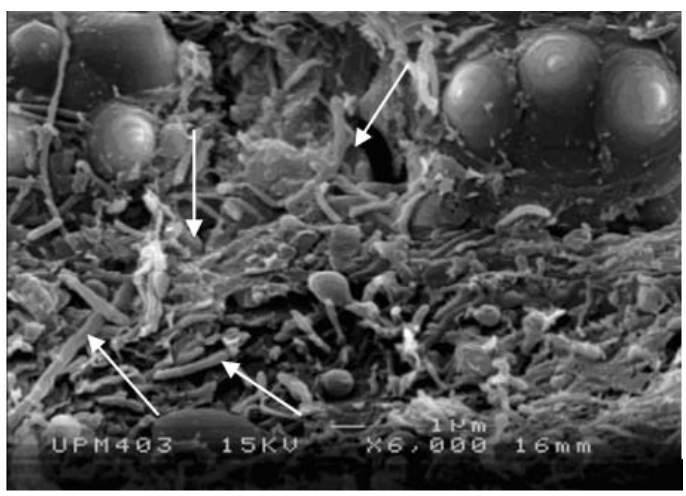

(b)

Fig. 1: SEM observation on the EFB compost sample at day 7 treatment (a): 1000X magnification and (b): $6000 \mathrm{X}$ magnification. The arrows showed the colonization of bacteria 
Am. J. Applied Sci., 7 (1): 56-62, 2010

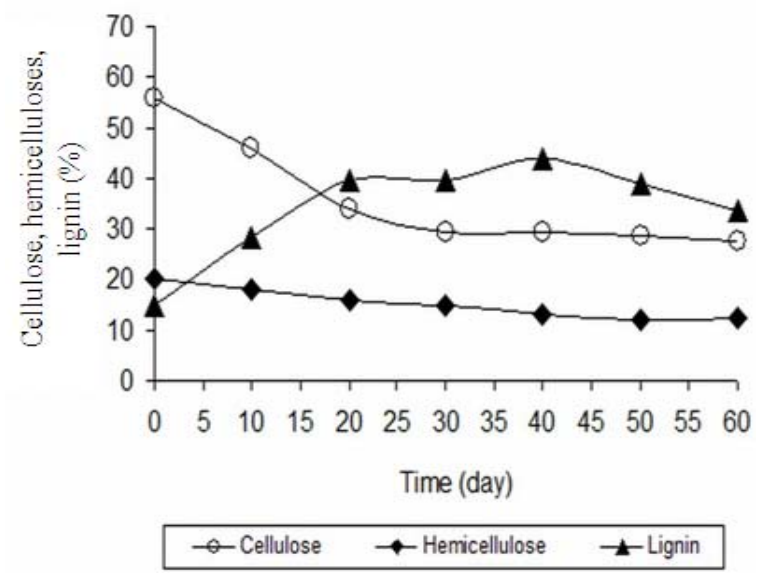

Fig. 2: The profiles of cellulose (०): Hemicellulose ( $\bullet)$ and lignin content $(\boldsymbol{\Delta})$ of EFB-POME compost sample throughout the treatment

Table 1: Chemical composition of shredded EFB and dewatered POME sludge

\begin{tabular}{lll}
\hline Parameters (\%) & EFB & Dewatered POME sludge \\
\hline Nitrogen & 0.04 & 3.54 \\
Carbon & 46.8 & 33.9 \\
Cellulose & 52.8 & 15.7 \\
Hemicellulose & 24.8 & 13.0 \\
Lignin & 15.7 & 32.3 \\
\hline
\end{tabular}

The cellulose content gradually decreased towards the end of composting process with $47.4 \%$ of reduction while lignin content has the opposite profiles with the increment of $57.1 \%$. The hemicellulose content was reduced slightly throughout composting process with the $25 \%$ of reduction (Fig. 2). The composition of compost at day 7 consisted of 45.8 cellulose, 17.1 hemicellulose and $28.3 \%$ lignin content, respectively. The lignin content $(32.3 \%)$ of the POME sludge was higher than the cellulose and hemicellulose composition as indicated in Table 1.

Enrichment and isolation of cellulose-producing bacteria: Pre-incubation of the cultures at $70^{\circ} \mathrm{C}$ in water bath for 1 day only shown the present of thermophilic spore-forming bacteria grown on the CMC agar plates after 3 days. The colonies exhibited small circular form with creamy color. These cultures form pellicles at their surfaces. The formation of spore occurred when the spore forming bacteria had dormant at high temperature $\left(70^{\circ} \mathrm{C}\right)$.

Morphological characterization: The isolated bacteria shown rod shape (Fig. 3a), gram negative bacteria and motile. Based on the SEM micrograph (Fig. 3b), it shown that the bacteria have rod shape with the size of 2-4 $\mu \mathrm{m}$.

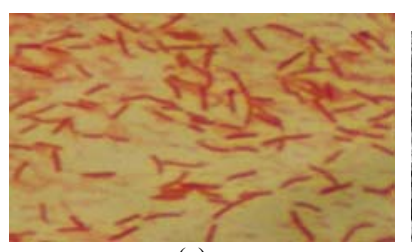

(a)

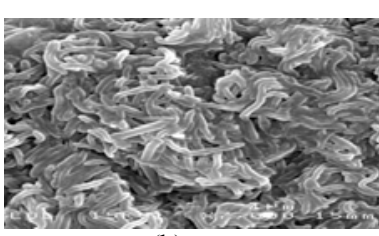

(b)
Fig. 3: Gram stain result viewed under 1000x light microscope (a) and scanning electron micrograph of isolated bacteria under 7000x (b)

Table 2: The 16 alignment matches for EB compost 1

\begin{tabular}{lll}
\hline & & Percentage \\
Accession No. & Species & Similarity \\
\hline EU621361 & Geobacillus pallidus & 99 \\
AY566220 & Bacillus sp. BS1 & 99 \\
AY583458 & Bacillus sp. E53-10 & 99 \\
AB089226 & Bacillus sp. G8 & 99 \\
AY566219 & Bacillus sp. BL8 & 99 \\
Z26930 & B.pallidus & 99 \\
EU250939 & Proteobacterium NFC7-B & 99 \\
DQ642094 & Geobacillus sp. T38 & 99 \\
EU816691 & Geobacillus pallidus clone LK5 & 99 \\
DQ642095 & Geobacillus sp. A60 & 99 \\
AY639816 & Bacillus sp. IS-2004 & 99 \\
AB040122 & Bacillus sp. B-3 & 99 \\
AB089233 & Bacillus sp. IZ3 & 99 \\
EU004569 & Geobacillus sp. HM06-07 & 99 \\
AB089220 & Bacillus sp. G2 & 99 \\
Z26931 & B.thermoalkalophilus & 98 \\
FM162562 & Pseudomonas veronii & Out of group \\
\hline
\end{tabular}

Meanwhile, the isolated bacteria also shown the absent of flagella and the bacteria moved in a whirl and jet motion. In this study, the isolated thermophilic bacteria were motile, rod shape, produced flat, cream-colored colonies, gram negative stain, 1-14 $\mu \mathrm{m}$ long and had spore-forming rod shape.

Detection of cellulase activity: The screening process of cellulolytic bacteria was conducted using the congo red test. Since the sole carbon source in the agar was $\mathrm{CMC}$, therefore the result of the test was a strong evident that cellulase was produced in order to degrade cellulose (Lynd et al., 2002; Wang et al., 2008). The isolated bacteria were identified by $16 \mathrm{~S}$ rDNA sequence analysis. A total of 831 nucleotides on the reverse sequence complement of 16S rRNA genes were determined. The sequences were entered into the Nucleotide-Nucleotide BLAST (NCBI BLAST) and percentage identities established. The highest identity for sample EB compost 1 was $99 \%$ with similarity to Geobacillus pallidus (Table 2). The 16S rRNA phylogenetic tree was constructed by Bioedit and Mega4 as shown in Fig. 5. In this study, the EUB 338 probe was hybridized with the isolated 16S rRNA 
which was exhibited red color. Figure 6 illustrated the abundance of eubacteria in thermophilic cellulaseproducing bacteria. Autofluorescence was created less image quality which shown reddish cloudy to the captured image.

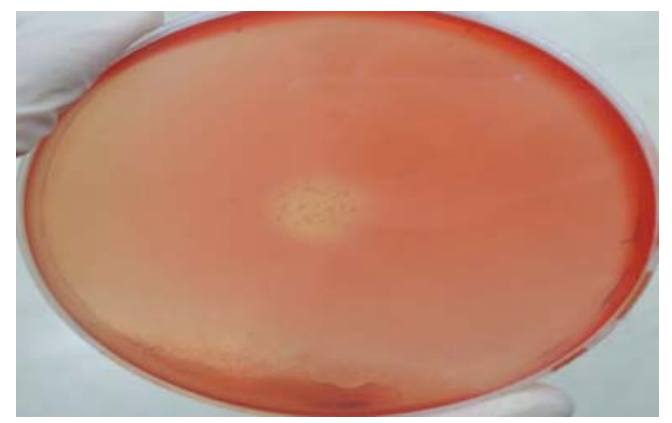

Fig. 4: Clear zone indicated the hydrolysis of CMC as a result of cellulases production by isolated Geobacillus pallidus

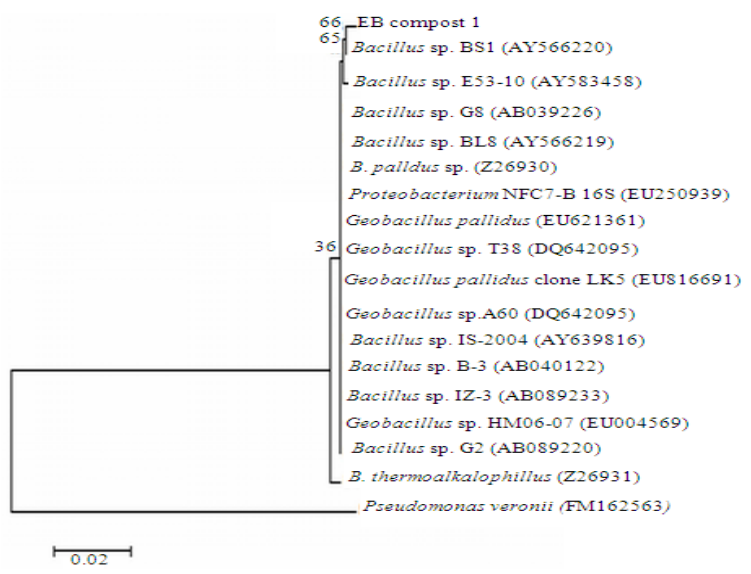

Fig. 5: Neighbor joining phylogenetic trees. The trees were generated using the 17 alignments matches

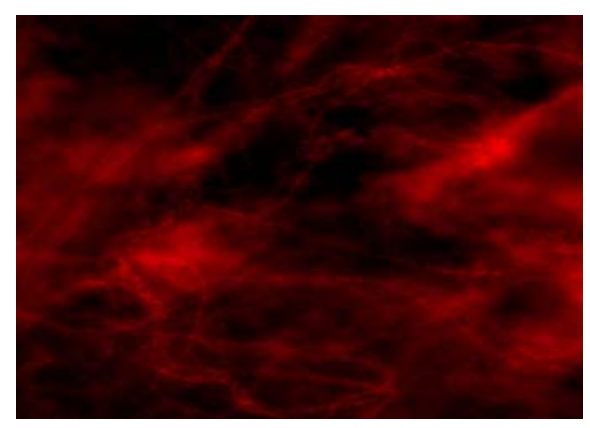

Fig. 6: FISH staining on pure culture of thermophilic cellulase-producing bacteria isolated from EFBPOME compost

\section{DISCUSSION}

The slightly alkaline $\mathrm{pH}$ might be due to an increase in ammonia generated by the biochemical reaction of nitrogen-containing materials and additional of partially treated POME to enrich the EFB compost (Baharuddin et al., 2009). The isolation was conducted at the initial stage of composting process to obtain the superior bacteria strain at thermophilic condition capable for the degradation of lignocellulosic material of EFB. The reduction of cellulose content may due to the microbial consumption while the increment of lignin content could due to the accumulation of nondegradable compost material and addition of POME sludge onto the composting piles throughout the treatment. Lignin forms an excellent strength barrier with cellulose and other carbohydrate to suppress the penetration of cellulolytic enzymes. The EFB lignin can be considered as structurally more complex than wood lignin which they are composed of syringyl and guaiacylpropane units together with small amount of phydroxyphenypropane units (Ibrahim and Azian, 2005).

The spore was heat resistance in the compost. In this study, the spore will germinate and multiplied when the condition are favourable with an agreement and reported by other researchers (Laaberki and Dworkin, 2008; Hassen et al., 2002). The isolated bacteria may respond directly to ambient condition or to temporal changes in stimulus intensity as reported by $\mathrm{Wu}$ et al. (2003). According to literature, Bacillus was gram-variable and endospore-forming bacteria (Banat et al., 2004). It was reported that Bacillus subtillis was moved in a whirl and jet motion neither individually nor in cell groups (Mendelson et al., 1999). According to Beffa et al. thermophilic oval-sporeforming Bacillus was isolated from compost and shown long rod shape with 2-3 $\mu \mathrm{m}$ long viewed under SEM (Beffa et al., 1996). Geobacillus debilis was isolated from cool soil environment as reported by Banat et al. (2004).

In this study, clear zone around the bacteria colonies after staining with congo red indicated the hydrolysis of $\mathrm{CMC}$ as a result of cellulases production (Fig. 4) and this phenomenon has been reported by Ibrahim and El-diwany (2007). Moreover, it was reported by Sirisena and Manamendra that Geobacillus strain was capable in hydrolyzing cellulose (Miyazaki et al., 2007). As detected from congo red method, the isolated strain had endo- $\beta-1,4$-glucanase activity. This was one of the enzymes required for the conversion of cellulose to glucose as reported by Sirisena and Manamendra (1995). According to Ariffin et al. (2008) cellulolytic bacteria, Bacillus pumilus EB3 was 
successfully isolated from EFB. The strain produced clear zone around the colony after staining with congo red on CMC agar.

It was reported that the 16S rRNA gene analysis of the isolated bacterium could characterize morphologically and its phylogenetic position (Chang et al., 1998). It has been reported that the isolated Geobacillus debilis had shown 91\% 16S rRNA gene sequence similarity to the sequence of Geobacillus pallidus (Lynd et al., 2002). Comparison of the mean distance phylogenetic tree had shown similar relationships. Fluorescent In Situ Hybridization (FISH) has been used primarily with prokaryotic communities and allows the direct identification and quantification of specific or general taxonomic groups of microorganisms within their natural microhabitat (Kenzaka et al., 1998). The group of eubacteria, archaea and methanogen can be distinguished with different labeled probes (Hill et al., 2000). The oligonucleotide probes (EUB338) used in this study has been shown to detect almost all eubacteria (Haruta et al., 2002). Drying touch preparations in air, locus-specific probe specificity and chemical composition of cell were the major contribution to autofluorescence (Szollosi et al., 1995; Ainsworth et al., 2006).

\section{CONCLUSION}

Cellulose-degrading bacteria namely EB compost 1 wasidentified and characterized a thermophilic with $99 \%$ similarity to Geobacillus pallidus. Considering its stability under high temperature (up to $60^{\circ} \mathrm{C}$ ) as well as neutral condition ( $\mathrm{pH} \mathrm{7)}$, the isolated strain may be useful for the industrial purpose. This study successfully isolated new bacteria strains from Empty Fruit Bunch (EFB) and Palm Oil Mil Effluent (POME) compost.

\section{ACKNOWLEDGEMENT}

The project was sponsored by Kyushu Institute of Technology, Japan and Felda Palm Industries Sdn. Bhd., Malaysia. The researchers would like to thank the management of Maokil Palm Oil Mill for their cooperation throughout the study. This study was financially supported by FELDA grant (67001) and Japan Society for Promotion of Science (JSPS).

\section{REFERENCES}

Ainsworth, T.D., M. Fine, L.L. Blackall and O.H. Guldberg, 2006. Fluorescence In situ hybridization and spectral imaging of coral-associated bacterial communities. Applied Environ. Microbiol., 72: 3016-3020. DOI: 10.1128/AEM.72.4.30163020.2006
Ariffin, H., N. Abdullah, M.S. Umikalsom, Y. Shirai and M.A. Hassan, 2008. Production of bacterial endoglucanase from pretreated oil palm empty fruit bunch by Bacillus pumilus EB3. J. Biosci. Bioeng. 106: 231-236. DOI: 10.1263/jbb.106.231

Baharuddin, A.S., M. Wakisaka, Y. Shirai, S.A. Aziz, N.A. Rahman and M.A. Hassan, 2009. Cocomposting of empty fruit bunches and partially treated palm oil mill effluents in pilot scale. Int. J. Agric. Res., 4: 69-78. http://scialert.net/asci/ascidetail.php?doi=ijar.2009. $69.78 \& \mathrm{kw}=$

Banat, I.M., R. Marchant and T.J. Rahman, 2004. Geobacillus debilis sp. nov., a novel obligately thermophilic bacterium isolated from a cool soil environment and reassignment of Bacillus pallidus to Geobacillus pallidus comb. Nov. Int. J. Syst. Evolution. Microbiol., 54: 2197-2201. DOI: 10.1099/ijs.0.63231-0

Beffa, T., M. Blanc, P.F. Lyon, G. Vogt, M. Marchiani, J.L. Fischer and M. Aragno, 1996. Isolation of thermus strains from hot composts $\left(60-80^{\circ} \mathrm{C}\right)$. Applied Environ. Microbiol., 65: 1723-1727 PMCID: PMC167946

Cai, Y.J., S.J. Chapman, J.A. Buswell and S.T. Chang, 1999. Production and distribution of endoglucanase, cellobiohydrolase and betaglucosidase components of the cellulolytic system of Volvariella volvacea, the edible straw mushroom. Applied Environ. Microbiol., 65: 553-559. PMID: 9925582

Chang, Y.C., M. Hatsu, K. Jung, Y.S. Yoo and K. Takamizawa, 1998. Degradation of a variety of halogenated aliphatic compounds by an anaerobic mixed culture. J. Fermentat. Bioeng., 86: 410-412. DOI: 10.1016/S0922-338X(99)89015-1

Dees, P.M. and W.C. Ghiorse, 2001. Microbial diversity in hot synthetic compost as revealed by PCR-amplified rRNA sequences from cultivated isolates and extracted DNA. FEMS Microbiol. Ecol., 35: 207-216. DOI: 10.1111/j.15746941.2001.tb00805.x PMID: 11295460

Haruta, S., M. Kondo, K. Nakamura, H. Aiba, S. Ueno, M. Ishii and Y. Igarashi, 2002. Microbial community changes during organic solid waste treatment analyzed by double gradient-denaturing gradient gel electrophoresis and fluorescence in situ hybridization. Applied Microbiol. Biotechnol., 60: 224-231. DOI: 10.1007/s00253-002-1074-9

Hassan, M.A., O. Nawata, Y. Shirai, N.A.A. Rahman, P.L. Yee, A. Arif and M.I. Abdul Karim, 2002. A proposal for zero emission from palm oil industry incorporating the production of polyhy droxyalkanoates from palm oil mill effluent. J. Chem. Eng. Jap., 35: 9-14. DOI: 10.1252/jcej.35.9 
Am. J. Applied Sci., 7 (1): 56-62, 2010

Hassen, A., K. Belguith, N. Jedidi, M. Cherif and A. Boudabous, 2002. Microbial characterization during composting of municipal solid waste. Biores. Technol., 80: 217-225. DOI: 10.1016/S0960-8524(01)00065-7

Hill, G.T.,N.A. Mitkowski, L. Aldrich-Wolfe, L.R. Emele, D.D. Jurkonie and A. Ficke, 2000. Methods for assessing the composition and diversity of soil microbial communities. Applied Soil Ecol. 15: 25-36. DOI: $10.1016 / \mathrm{S} 0929-1393(00) 00069-X$

http://www.microbiology.columbia.edu/faculty/pdf /249-Laaberki-final.pdf

Ibrahim, A.S.S. and A.I. El-diwany, 2007. Isolation and identification of new cellulases producing thermophilic bacteria from an egyptian hot spring and some properties of the crude enzyme. Aust. J. Basic Applied Sci., 1: 473-478. http://www.insinet.net/ajbas/473-478.pdf

Ibrahim, M.N.M. and H. Azian, 2005. Extracting soda lignin from the black liquor of oil palm empty fruit bunch. J. Technol., 42: 11-20.

Iyengar, S.R. and P.P Bhave, 2005. In-vessel composting of household wastes. J. Waste Manage., 26: 1070-1080. DOI: 10.1016/j.wasman.2005.06.011 PMID: 16153815

Kenzaka, T., N. Yamaguchi, K. Tani and M. Nasu, 1998. rRNA targeted fluorescent In situ hybridization analysis of bacterial community structure in river water. Microbiology, 144: 2085-2093. PMID: 9720029

Laaberki, M.H. and J. Dworkin, 2008. Death and survival of spore-forming bacteria in the caenorhabditis elegans intestine. Symbiosis, 46: 95-100.

Lee, S.M and Y.M. Koo, 2001. Pilot-scale production of cellulose using trichoderma reesei Rut C-30 in fed-batch mode. J. Microbiol. Biotechnol., 11: 229-233. http://cat.inist.fr/?aModele $=$ afficheN\&cpsidt $=1067767$

Lynd, L.R., P.J. Lee, Paul Weimer, W.H. van Zyl and I.S. Pretorius, 2002. Microbial cellulose utilization. Fundament. Biotechnol. Am. Soc. Microbial, 66: 506-577. DOI: 10.1128/MMBR.66.3.506-577.2002

Mendelson, N.H., A. Bourque, K. Wilkening, K.R. Anderson and J.C. Walkins, 1999. Organized cell swimming motions in bacillus subtilis colonies: Patterns of short-lived whirls and jets. J. Bacteriol., 181: 600-609. PMID: 9882676

Miyazaki, K., C. Irbis, J. Takada and A. Matsuura, 2007. An ability of isolated stains to efficiently cooperate in ethanolic fermentation of agricultural plant refuse under initially thermophillic conditions: Oxygen depletion process appended to Consolidated Bioprocessing (CBP). Biores. Technol., 99: 1768-1775. DOI: 10.1016/j.biortech.2007.03.045
Sekiguchi, Y., Y. Kamagata, K. Nakamura, A. Ohashi and H. Harad, 1999. Fluorescence in situ hybridization using 16s rRNA-targeted oligonucleotides reveals localization of methanogens and selected uncultured bacteria in mesophilic and thermophilic sludge granules. Applied Environ. Microbiol., 65: 1280-1288. PMID: 10049894

Shibata, M., M. Varman, Y. Tono, H. Miyafuji and S. Saka, 2008. Characterization in chemical composition of the oil palm (Elaeis guineensis). J. Jap. Inst. Energy, 87: 383-388. DOI: 10.3775/jie.87.383 JOIJST.JSTAGE/jie/87.383

Sirisena, D.M. and T.P. Manamendra, 1995. Isolation and characterization of cellulolytic bacteria from decomposing rice straw. J. Nat. Sci. Country Sri Lanka, 23: 25-30.

Szollosi, S., S.J. Lockett, M. Balázs and F.M. Waldman, 1995. Autofluorescence correction for fluorescence in situ hybridization. Cytometry, 20: 356-361. DOI: 10.1002/cyto.990200412

Thambirajah, J.J., M.D. Zulkali and M.A. Hashim, 1995. Microbiological and biochemical changes during the composting of oil palm empty fruit bunches. Effect of nitrogen supplementation on the substrate. Biores. Technol., 52: 133-144. DOI: 10.1016/0960-8524(95)00008-3

Tuomela, M., M. Vikman, A. Hatakka and M. Itävaara, 2000. Biodegradation of lignin in a compost environment: A review. Biores. Technol., 72: 169-183. DOI: 10.1016/S0960-8524(99)00104-2

Umi-kalsom, M.S., Ariff A.B., and Zulkifli H.S, 1997. The treatment of OPEFB fibre for subsequent use as substrate for cellulose production by Chaetomium globusum kunze. Bioresour. Technol., 62: 1-9.

Wang, C.M., C.L. Shyu, S.P. Ho and S.H. Chiou, 2008. Characterization of a novel thermophilic, cellulose degrading bacterium Paenibacillus sp. strain B39. Lett. Applied Microbiol., 47: 46-53. DOI: 10.1111/j.1472-765X.2008.02385.x

Wu, G., Y. Feng and S.A. Boyd, 2003. Characterization of bacteria capable of degrading soil-sorbed biphenyl. Bull. Environ. Contaminat. Toxicol., 71: 768-75. DOI: 10.1007/s00128-003-0198-7i

Ziad E., A. Maraqa, W. Owais and A. Khraisat, 2007. Isolation and characterization of new thermophilic bacteria in Jordan. Internet J. Microbiol., 3: 2-2. 